University of Chicago Law School

Chicago Unbound

Journal Articles

Faculty Scholarship

2016

\title{
Open Letter On Ethical Norms In Intellectual Property Scholarship
}

Robin Feldman

Mark Lemley

Jonathan Masur

Arti K. Rai

Follow this and additional works at: https://chicagounbound.uchicago.edu/journal_articles

Part of the Law Commons

\section{Recommended Citation}

Robin Feldman, Mark Lemley, Jonathan Masur \& Arti K. Rai, "Open Letter On Ethical Norms In Intellectual Property Scholarship," 29 Harvard Journal of Law and Technology 1 (2016).

This Article is brought to you for free and open access by the Faculty Scholarship at Chicago Unbound. It has been accepted for inclusion in Journal Articles by an authorized administrator of Chicago Unbound. For more information, please contact unbound@law.uchicago.edu. 
Harvard Journal of Law \& Technology

Volume 29, Number 2 Spring 2016

\title{
OPEN LETTER ON ETHICAL NORMS IN INTELLECTUAL PROPERTY SCHOLARSHIP ${ }^{1}$
}

\author{
Robin Feldman, Mark A. Lemley, Jonathan S. Masur \& Arti K. Rai*
}

As intellectual property ("IP") scholars, we write this letter with aspirations of reaching the highest ethical norms possible for our field. Changes in the field of IP make it incumbent upon us to look inward, examine our current practices, and begin to frame norms that we hope can apply across the field of legal academia.

We have noted an influx of large contributions from corporate and private actors who have an economic stake in ongoing policy debates in the field. Research funding has increased as IP issues have become more salient in both the political and business realms. And it has coincided with a decline in university funding for basic academic research. Some dollars come with strings attached, such as the ability to see or approve academic work prior to publication or limitations on the release of data. Some dollars simply arrive as donations to IP programs or centers, or in the form of travel grants and other attractive gifts.

At the same time, IP scholars have become more engaged in policy advocacy, the writing of amicus briefs, and the practice of law. In general, we think this is a salutary development. Courts regularly complain about scholarship being unconnected to the real world, ${ }^{2}$ and law students worry that they are not being trained to succeed in practice. $^{3}$ Greater engagement between scholars and the world of practice can help solve both problems and can also bring a thoughtful, more

1 (C) 2016 Robin Feldman, Mark A. Lemley, Jonathan S. Masur \& Arti K. Rai.

* Robin Feldman is the Harry \& Lillian Hastings Professor at the University of California Hastings College of the Law. Mark A. Lemley is the William H. Neukom Professor at Stanford Law School and is also a partner at Durie Tangri LLP. Jonathan S. Masur is the John P. Wilson Professor of Law at University of Chicago Law School. Arti K. Rai is the Elvin R. Latty Professor at Duke Law School.

We thank a large number of our colleagues for helpful comments that have shaped these norms, including both signatories and nonsignatories. Thanks to John Allison, Jim Bessen, Miriam Bitton, Colleen Chien, Ralph Clifford, Wes Cohen, Jorge Contreras, Dennis Crouch, Mark Davison, Rochelle Dreyfuss, James Grimmelman, Ariel Katz, Brian Love, David Opderbeck, Lisa Larrimore Ouellette, Michael Risch, Josh Sarnoff, Jason Schultz, Dave Schwartz, Ted Sichelman, Matt Spitzer, and Jennifer Urban, among many others.

2. See, e.g., Brent Newton, Scholar's Highlight: Law Review Articles in the Eyes of the

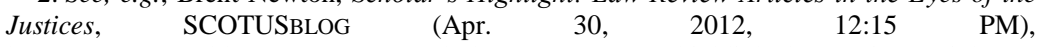
http://www.scotusblog.com/2012/04/scholar\%E2\%80\%99s-highlight-law-review-articlesin-the-eyes-of-the-justices/ [http://perma.cc/CDA7-K3GB] (citing the derogatory comments three Supreme Court Justices made about law review articles).

3. See, e.g., BRIAN Z. TAMANAHA, FAILING LAW SCHOOLS 135-59 (2012). 
unbiased perspective to legislative and judicial debates traditionally dominated by interested parties. At the same time, however, IP scholars who are also engaged in practice or advocacy must struggle to keep their academic and advocacy roles separate.

We cannot imagine that any academic believes that his or her judgment is subject to purchase. Nevertheless, the flow of dollars can have an insidious effect on values scholars hold dear in academia. We have seen evidence in other fields that researchers who receive gifts and support can have an uncanny tendency to find results that would please their benefactors. ${ }^{4}$ One must be mindful of the delicate pull of friends with money.

Funding can have other subtle effects on academic discourse. In the highest tradition of academic inquiry, scholars should strive to be open to the comments, suggestions, and views of others - learning from colleagues in the field and modifying their inclinations as they hear persuasive arguments. As a community, scholars benefit from constant effort to shape and improve each other's thinking, and such effort makes the entire field intellectually stronger and more valuable. We worry that an influx of money paid to those who take certain positions can cause people to become locked into those positions rather than being open to academic discussion and allowing one's perspective to evolve as part of that discourse. In the long term, the influx of money has the potential to create polarization in the field, creating a situation in which different sides speak only to those with similar perspectives. Such a result could seriously weaken the potential for scholars to strengthen their work by subjecting it to critique and taking seriously the scrutiny it receives.

Finally, we are mindful of the need to protect the role of the academic as a trusted source of reliable information for policymakers and society at large. The issues described above run the risk of creating the impression in the minds of the public that academics are lobbyists rather than scholars - with the accompanying loss of trust.

We do not intend to be critical of any individual academic or the field as a whole. It would be improper to criticize scholars for violating ethical norms when no such norms exist across legal academia. Rather, our goal is to bring attention to the dramatic changes that are occurring in the field, highlight potential pitfalls, and suggest a set of ethical norms to which we will strive to adhere.

IP law is not the first field to encounter these problems. In fact, legal academics are well behind the curve in grappling with the implication of these issues and establishing uniform guidelines. Studies of research in the field of medicine have long identified concerns about

See infra note 9 and accompanying text. 
the connection between sponsorship and results. ${ }^{5}$ For example, a 2003 study in the Journal of the American Medical Association ("JAMA") concluded that "industry-sponsored research tends to draw proindustry conclusions." "In a meta-analysis ${ }^{7}$ of eight articles addressing the issue of industry-sponsored research, which together had themselves covered more than eleven hundred original medical research studies, Bekelman et al. found that industry-sponsored trials were 3.6 times more likely to reach conclusions favorable to industry than those without industry sponsorship. ${ }^{8}$ In addition to more positive outcomes, the articles also raised concerns about subtle judgment issues in the design of the sponsored medical trials that could influence results. ${ }^{9}$

Direct sponsorship of research is not the only cause of concern. Studies have concluded that other types of financial ties besides direct sponsorship can have an effect on results. For example, a 1998 study published in the New England Journal of Medicine examined sixtynine articles related to a particular type of pharmaceutical. ${ }^{10}$ The study showed that authors whose research supported the use of the pharmaceutical were significantly more likely to have financial relationships with the manufacturers than those who were neutral or critical. ${ }^{11}$

5. See generally, e.g., Thomas Bodenheimer, Uneasy Alliance: Clinical Investigators and the Pharmaceutical Industry, 342 NEW ENG. J. MED. 1539 (2000); Drummond Rennie, Thyroid Storm, 277 J. AM. MED. Ass'N 1238 (1997); Justin Gillis, A Hospital's Conflict of

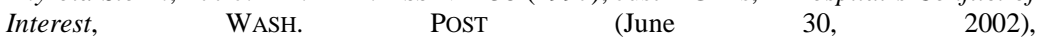
http://www.washingtonpost.com/archive/politics/2002/06/30/a-hospitals-conflict-ofinterest/22bf0db8-e014-4f57-bece-f0998d394396/ [http://perma.cc/66LR-6JB4]; Philip J. Hilts, Company Tried To Block Report That Its H.I.V. Vaccine Failed, N.Y. TIMES (Nov. 1, 2000), http://www.nytimes.com/2000/11/01/us/company-tried-to-block-report-that-its-hivvaccine-failed.html [http://perma.cc/9S2F-T75F]; Duff Wilson \& David Heath, Uninformed Consent, SEATTL TIMES, http://old.seattletimes.com/uninformed_consent/ [http://perma.cc/FRR4-VEPK].

6. Justin E. Bekelman et al., Scope and Impact of Financial Conflicts of Interest in Biomedical Research: A Systematic Review, 289 J. AM. MED. Ass'N 454, 463 (2003).

7. A meta-analysis is one that "thoroughly examine[s] a number of valid studies on a topic and mathematically combine[s] the results using accepted statistical methodology to report the results as if it were one large study." Introduction to Evidence-Based Practice: Types of Studies, DUKE U. MED. CTR. LIBR. \& ARCHIVES, http://guides.mclibrary.duke.edu/c.php?g=158201\&p=1036068 [http://perma.cc/KH86F3PX] (last updated Jan. 19, 2016, 2:57 PM)

8. See Bekelman et al., supra note 6, at 456; Peter Whoriskey, As Drug Industry's Influence over Research Grows, So Does the Potential for Bias, WASH. POST (Nov. 24, 2012), http://www.washingtonpost.com/business/economy/as-drug-industrys-influence-overresearch-grows-so-does-the-potential-for-bias/2012/11/24/bb64d596-1264-11e2-be82c3411b7680a9_story.html [http://perma.cc/24H8-GDRL] (describing the JAMA study and its main finding).

9. See Bekelman et al., supra note 6, at 456, 459; Whoriskey, supra note 8.

10. Henry Thomas Stelfox et al., Conflict of Interest in the Debate over Calcium-Channel Antagonists, 338 NEW ENG. J. OF MED. 101, 103 (1998).

11. Id. 
As concerns have increased about financial ties outside of direct sponsorship of research, studies have increasingly focused on unveiling additional financial conflicts of interests that subtly influence physician practice. For example, a recent analysis by Robertson et al. summarized several studies on the effects of pharmaceutical industry gifts in the form of paid travel and accommodation, food and beverages, sponsorship for continuing medical education, as well as free tickets to cultural and sporting events. ${ }^{12}$ Robertson et al. tracked changes in prescribing behavior after physicians received such benefits. Notably, physicians who received money for continuing medical education insisted that such funding would not influence their medical practice. ${ }^{13}$ Despite this conviction, post-sponsorship prescribing patterns shifted toward endorsement of the sponsoring pharmaceutical brands. ${ }^{14}$

Concerned that public trust in medical research could be seriously eroded, ${ }^{15}$ the medical research field has engaged in reviews of its own policies that have led to revisions of various ethical rules. Many, although not all, highly respected medical journals now require authors to submit extensive financial contribution reports along with their articles. $^{16}$ The Pharmaceutical Research and Manufacturers of America ("PhRMA"), which represents biopharmaceutical research companies, introduced a Code of Ethics designed to limit the pharmaceuticalphysician relationship. ${ }^{17}$ Moreover, the Affordable Care Act (2010), in order to increase transparency, requires pharmaceutical companies to report financial gifts to physicians, even low-value purchases, such as lunch. ${ }^{18}$ ProPublica, a public interest, investigative journalism non-

12. Christopher Robertson et al., Effect of Financial Relationships on the Behaviors of Health Care Professionals: A Review of the Evidence, 40 J.L. MED. \& ETHICS 452, 459-61 (2012).

13. Id. at 461 (citing M.A. Bowman \& D.L. Pearle, Changes in Drug Prescribing Patterns Related to Commercial Company Funding of Continuing Medical Education, $8 \mathrm{~J}$. CONTINUING EDUC. HeAlTH PROFS. 13 (1988)).

14. Id.

15. Bekelman et al., supra note 6, at 455. See generally Jordan J. Cohen, Trust Us To Make a Difference: Ensuring Public Confidence in the Integrity of Clinical Research, 76 ACAD. MED. 209 (2001); Donna Shalala, Protecting Research Subjects - What Must Be Done, 343 NEW ENG. J. MED. 808 (2000).

16. See generally, e.g., George D. Lundberg \& Annette Flanagin, New Requirements for Authors: Signed Statements of Authorship Responsibility and Financial Disclosure, 262 J. AM. MED. ASS'N 2003 (1989); Author Responsibilities - Conflicts of Interest, INT'L COMMITTEE MED. J. EDITORS, http://www.icmje.org/recommendations/browse/roles-andresponsibilities/author-responsibilities--conflicts-of-interest.html [http://perma.cc/YP7YHRSU].

17. See Phrma, Code on Interactions with HealthCare Professionals (2008), http://www.phrma.org/sites/default/files/pdf/phrma_marketing_code_2008.pdf [http://perma.cc/ZKN4-VM88].

18. See Patient Protection and Affordable Care Act, 42 U.S.C. § 1320a-7h(a)(1) (2012). 
profit, compiles and publishes this data on its website. ${ }^{19}$ In general, academics in the medical field have organized policies and implemented standards that aim to preserve the academy's integrity, objectivity, and ultimately, its ability to convey important findings.

Objectivity is a general scholarly goal that applies throughout all fields of research, even beyond pharmaceuticals. A 2015 New York Times article described controversy surrounding Coca-Cola's work with scientists to promote the conclusion that solutions to the nation's obesity problem should focus on exercise, rather than reducing caloric intake. ${ }^{20}$ The press report noted that the company, which would benefit considerably from any shift away from efforts to reduce consumption of sugary drinks, had partnered with respected scientists to promote this message through medical journals, conferences, and social media, including funding a nonprofit organization to advance the campaign. ${ }^{21}$ In the field of economics, a British study examined the financial affiliations of prominent academic financial economists who were associated with groups proposing financial reforms in the wake of the 2008 financial crisis. ${ }^{22}$ The study found that while the academic economists frequently had private affiliations with the potential to raise conflicts of interest issues, the economists disclosed those affiliations infrequently and inconsistently. ${ }^{23}$ Similarly, in September 2015, the New York Times published an article describing troubling ties between academics and industry on both sides of the debate concerning genetically modified crops. ${ }^{24}$ The article described corporations providing what it termed "special "unrestricted grants" to academics. $^{25}$ It also suggested that companies had paid for academics to make lobbying trips to Capitol Hill and had published articles under the names of prominent academics - articles that were, in some cases, drafted by industry consultants rather than the scholars. ${ }^{26}$

19. See Lena Groeger et al., Dollars for Docs: How Industry Dollars Reach Your Doctors, PROPUBLICA (July 1, 2015), https://projects.propublica.org/docdollars/ [http://perma.cc/A5H7-9QQ5].

20. Anahad O'Connor, Coca-Cola Funds Scientists Who Shift Blame for Obesity Away from Bad Diets, N.Y. Times (Aug. 9, 2015), http://well.blogs.nytimes.com/2015/08/09/coca-cola-funds-scientists-who-shift-blame-forobesity-away-from-bad-diets/?_r=0 [perma.cc/SCW9-Z277].

21. Id.

22. See Jessica Carrick-Hagenbarth \& Gerald A. Epstein, Dangerous Interconnectedness: Economists' Conflicts of Interest, Ideology and Financial Crisis, 36 CAMBRIDGE J. ECON. 43, 43 (2012).

23. Id. at $44-45$.

24. See Eric Lipton, Food Industry Enlisted Academics in G.M.O. Lobbying War, Emails Show, N.Y. TIMES (Sept. 5, 2015), http://www.nytimes.com/2015/09/06/us/food-industryenlisted-academics-in-gmo-lobbying-war-emails-show.html?_r=0 [perma.cc/H8QS-PLXL]. 25. Id.

26. Id. 
In the fields of scientific and medical research, journals and government funding sources can serve as important gatekeepers and referees. A peer-reviewed medical journal could, in theory, reject an artiarticle if there is reason to believe that the work is compromised by financial interests. Even asking about financial interests can lead to a check on behavior. Thus, if journals require authors to disclose gifts or financial ties above a certain amount, researchers may be moved to reject anything above that amount in anticipation of having to answer the question at the publication gate. Such gatekeepers can also impose transparency by requiring authors to disclose information in a way that is accessible and useful. ${ }^{27}$ Questions and requirements from government funding agencies, such as the National Institutes of Health ("NIH") and the National Science Foundation ("NSF"), can have similar effects. Finally, the peer-review process encourages authors to tone down unsupported claims ${ }^{28}$ and has the potential to tease out methodological concerns. Although serious criticism and debate remain over the effectiveness of these ethical rules, peer review supplies both a mechanism to implement the rules and an awareness of their importance.

In contrast to medical research, legal research lags well behind, both in terms of the establishment of ethical codes and methods of enforcing those codes. The overwhelming majority of legal journals are not peer-reviewed. ${ }^{29}$ Rather, the articles are chosen and edited by law students whose knowledge of methodological flaws and potential biases may be limited. Law journals generally do not request information on conflicts of interest and do not require disclosure of such information. Similarly, the legal field lacks organizations, such as the $\mathrm{NIH}$ and NSF, that have either the purse strings or the bully pulpit to impose meaningful ethical rules. Legal authors may occasionally seek federal funds to support research, but that is far from the norm. As a result, it is unsurprising that behavioral norms similar to those in the scientific fields have yet to emerge.

In some corners, however, conflict of interest rules are beginning to have an impact on the legal academy. Consider Harvard University's policy, which was promulgated in response to concern over po-

27. However, offering an avalanche of information, with the relevant piece buried somewhere therein, does not constitute useful disclosure and should be eschewed under ethical disclosure best practices.

28. See, e.g., Whoriskey, supra note 8 (reporting that New England Journal of Medicine peer reviewers demanded authors of a study sponsored by pharmaceutical companies to tone down the safety claims in a report on the drug Avandia).

29. Richard A. Posner, Against the Law Reviews, LEGAL AFF. (Nov.-Dec. 2004), http:// www.legalaffairs.org/issues/November-December-2004/review_posner_novdec04.msp [perma.cc/485H-LGYK]. 
tential conflicts of interest at the medical school ${ }^{30}$ and applies broadly to all Harvard academics, including legal academics. ${ }^{31}$ It "requires public disclosure of all relevant faculty financial interests; prohibits most gifts from industry; regulates faculty members' participation in industry speakers' bureaus; and restricts industry involvement in continuing medical education." 32 This type of conflict of interest policy could serve as a model for legal academia and offers a good starting point for thinking about the issues as they arise in the legal context.

The bias that may result from a financial conflict of interest is, of course, not the only bias that can affect either legal or scientific results. The pressure to produce publishable results, to say something of significance that will garner attention, to reevaluate the accepted norm, or to otherwise approach the data in a way that will lead toward certain conclusions, can affect any inquiry. ${ }^{33}$ Moreover, few scholars would argue that we are ever able to operate in the realm of perfect objectivity - whether as legal academics or scientists. ${ }^{34}$ Nevertheless, striving for the greatest objectivity possible is a worthwhile goal, and creating the transparency that will allow other academic colleagues to press us toward objectivity is essential to that end. ${ }^{35}$ With this in mind, we believe that we can borrow from the experience of medical science to begin building a set of cultural and ethical norms for IP scholars.

In addition to transparency about financial conflicts of interest, the medical and life science communities have also had to confront

30 See Duff Wilson, Harvard Medical School in Ethics Quandry,

http://www.nytimes.com/2009/03/03/business/03medschool.html?hp [perma.cc/BF2XUAMH].

31. See Financial Conflict of Interest Policy, HARVARD UNIV., http://vpr.harvard.edu/ pages/financial-conflict-interest-policy [perma.cc/PS9W-V737].

32. See Addressing Conflicts of Interest, HARvard MAGAZINE (July-Aug. 2012), http://harvardmagazine.com/2012/07/addressing-conflicts-of-interest [perma.cc/32SKRSQA] (discussing revisions to the University's policy).

33. See Daniele Fanelli, Do Pressures to Publish Increase Scientists'Bias? An Empirical Support from US States Data, 5 PLOS ONE e10271, 1, 4 (Apr. 21, 2010), http://www.ncbi. nlm.nih.gov/pmc/articles/PMC2858206/pdf/pone.0010271.pdf [perma.cc/MB6K-QRJB]; see also Jeffrey M. Drazen, Editorial, Believe the Data, 367 NEw ENG. J. MED. 1152, 1152 (2012) (noting that non-financial incentives include "academic promotion and recognition . . . to ensure that their studies change practice"); Bekelman et. al., supra note 6, at 463 (asserting that industry bias exacerbates publication bias against negative results in favor of positive results); $c f$. $i d$. (discussing other forms of financial bias, such as receiving increased royalties from requiring their own textbooks for courses).

34. See Robin FeldMAN, THE ROLE OF SCIENCE IN LAW 82-83, 85-87 (2009) (discussing various schools of legal thought, including Legal Realism, and the limitations on objectivity in the art of law); id. at 133-38 and accompanying notes 326-42 (discussing the philosophy of science and limitations on the perfection of scientific knowledge).

35. See id. at 88-89 and accompanying notes 192-93 (noting that some discipline is imposed by the legal system's requirement that one's subjective reasoning — or desire wrapped in reason - must gain acceptance from the rest of the legal community). 
squarely the issue of data disclosure. As these fields have recognized, and as the broader scientific community has long understood, disclosure of the data necessary to replicate a particular research result is important protection against spurious claims. ${ }^{36}$ In recent years, independent investigators who were given the opportunity to access and reanalyze data underlying published results of clinical trials have challenged many of those results as invalid or incomplete. ${ }^{37}$ Citing these independent studies, the Institute of Medicine ("IOM") recently recommended a norm of expeditious sharing of all clinical trial data necessary to support results in a publication. ${ }^{38}$ While the IOM recommendation focuses on clinical scientists, a 2003 report by the National Academy of Sciences ("NAS") stresses the obligations of all life scientists to make freely available "the data, algorithms, or other information that is central or integral to the publication - that is, whatever is necessary to support the major claims of the paper and would enable one skilled in the art to verify or replicate the claims." 39 Additionally, according to the NAS, authors should provide data "in a form on which other scientists can build with further research."40 Since 2003, NIH has required researchers applying for more than $\$ 500,000$ in funding to submit a plan for data sharing. ${ }^{41}$

As for the social sciences, in 1995, prominent political scientist Gary King enunciated a "replication standard." ${ }^{, 42}$ Under this standard, "sufficient information exists with which to understand, evaluate, and build upon a prior work if a third party could replicate the results without any additional information from the author." 43 With the rise of empirical legal studies, including empirical studies of intellectual property, the replication standard has become relevant for a significant subset of IP scholarship as well.

36. See, e.g., Arti Kaur Rai, Regulating Scientific Research: Intellectual Property Rights and the Norms of Science, 94 Nw. U. L. REV. 77, 90-91 (1999) (discussing that the communalism norm of the scientific ethos generally takes a negative view of secrecy).

37. InST. OF MED. OF THE NAT'L ACADS., SHARING CliniCAL TRIAL DATA: MAXIMIZING BENEFITS, MINIMIZING RISK (2015), http://www.nap.edu/read/18998/chapter/1 [perma.cc/7LQE-KSY6].

38. Id. at . 80-82 ("Recommendation 1: Stakeholders in clinical trials should foster a culture in which data sharing is the expected norm, and should commit to responsible strategies aimed at maximizing the benefits, minimizing the risks, and overcoming the challenges of sharing clinical trial data for all parties.").

39. NAT'L RESEARCH COUNCIL OF THE NAT'L ACADS., SHARING PUblicATION-RELATED DATA AND MATERIALS: RESPONSIBILITIES OF AUTHORSHIP IN THE LIFE SCIENCES 5 (2003), http://www.nap.edu/read/10613/chapter/1 [perma.cc/PMH8-D82G].

40. Id. at 34 .

41. NAT'L Inst. OF HeAlth, Notice No. NOT-OD-03-032, FinAl NIH StatemENT ON SHARING RESEARCH DATA, (2003), http://grants.nih.gov/grants/guide/notice-files/NOTOD-03-032.html [perma.cc/D3EZ-WHCN].

42. Gary King, Replication, Replication, 28 PS: POL. SCI. \& POL. 444, 444 (1995).

43. Id. 


\section{NORMS FOR IP SCHOLARSHIP}

With these considerations in mind, we urge legal scholars to adopt a set of professional ethical norms governing disclosure, transparency, and conflicts of interest. These norms should serve to guide the conduct of academics and other researchers, as well as to establish benchmarks for future guidelines and standards. With these norms, we seek to promote three related objectives. The first is transparency: members of the academic community should disclose any monetary or related inducements that might have the potential to influence scholarly research or create the perception that scholarly research has been unduly influenced. The second is to reduce the potential for overt or subconscious bias to affect scholarly research. Members of the academic community should seek wherever possible to minimize or eliminate outside influences that might inject bias or the appearance of bias into research. The third is to facilitate replicability and examination of existing work by requiring, to the fullest extent possible, the disclosure of the data underlying it.

We thus offer the following suggested professional norms, which we hereby agree to adopt with respect to our own work. Similar norms have been widely adopted throughout the life sciences and social sciences, in some cases by rule of the governing professional organizations or academic publishers. We believe that legal scholars should abide by norms that are at least as stringent with respect to transparency and avoiding bias.

1. Research disclosure. We agree to disclose any sources of funding that contributed to the production of any given piece of research. We will disclose that funding source when the work is submitted for publication and on the work itself when the work is published or otherwise made publicly available. Contribution includes both payment to the author for the production of a piece of research and money spent to cover the costs of research assistance, data acquisition, and the like.

2. General personal disclosure. We agree to disclose prominently, either on our faculty websites or in an equivalent venue, all sources of funding we have received and all paid consulting or legal representation agreements we have made that are in any way relevant to our research or concern the same subject matter as our research. This includes an ongoing consulting relationship with a law firm or company. Ongoing relationships include relationships where compensated work has been completed but there is an expectation of future compensated work. This disclosure is required even if it does not directly impact, or involve the funding of, any particular research project. A general statement that a scholar receives money from various sources is not sufficient to satisfy this disclosure obligation. However, no dis- 
closure is required if the amount of money involved is less than $\$ 1000$ or if it constitutes only compensation for reasonable travel expenses. It is also not necessary to disclose personal equity holdings or ownership stakes, although we note in our "Call for Action" that other institutions involved in legal academic governance may wish to explore this issue.

We understand that in the course of legal practice or other types of consulting arrangements the fact of representation of a particular client may itself be confidential information for a time. The pledge is not designed to prevent such representation or bar such confidentiality. But the fact of representation should be disclosed as soon as the rules of practice permit, and if possible, the fact of representation should be disclosed even when the client cannot be. In addition, scholars should refrain from publishing academic work on the subject of the representation until such disclosure is feasible. ${ }^{44}$

3. Institutional disclosure. We agree to disclose all sources of funding for any institute, center, conference, clinic, or other institution we direct or manage on that institution's website. If there is more than one source of funding, we agree to indicate which of the sources of funding are major sources or represent a substantial share of the institution's overall funding.

4. No quid pro quo. We agree to refrain from engaging in any research in which conclusions or outcomes are dictated by a third party in exchange for funding. This does not prevent the preparation of briefs, legal memos, or white papers on behalf of clients, but any such document should make clear that the author is acting as an advocate and not an academic in preparing that document.

5. No prior approval. We agree to refrain from engaging in any research where a third party will have the right to approve or disapprove of the research before it is made public, except in order to protect the privacy or confidentiality of one or more individuals.

6. Data disclosure and replication. Consistent with applicable rules governing human subjects protection, we agree to strive for replicability of our published empirical research. Ideally, data needed to replicate the results in a published empirical paper should be made accessible to other academics at the time the paper is published. If the data set needed to replicate the results in a published paper cannot be

44. We intend for the phrase "on the subject of the representation" to be interpreted broadly. For instance, if a faculty member were currently employed by a client to represent the client in making an argument regarding patent validity under $\S 101$ of the Patent Act, that faculty member should not publish academic work on any aspect of $\S 101$ doctrine that is relevant to the case until the representation can be disclosed or until it has concluded. However, the faculty member would remain free to publish academic work on other aspects of patent law. 
made available, but the database from which the data set was derived is accessible to other academic researchers, we agree to describe in detail how replication can be accomplished by these researchers. We further agree to disclose any other materials necessary to replicate research findings, including formulae and other algorithms.

We consider the use of data accessible to other academics (facilitating replicability) to be a best practice that academics should engage in whenever possible. However, we realize that in some cases it may be impossible to obtain data without providing for nondisclosure beyond standard measures used to protect the identities of human subjects. Accordingly, we do not believe it is a violation of ethical norms to publish a paper that relies on data that is unavailable to other academics and cannot be replicated, but that fact should be disclosed in the paper itself.

7. Collegiality and open inquiry. We agree to remain open to arguments on all sides and engage in discussion using language and logic appropriate to the highest ethical standards of academic discourse and inquiry.

8. Dispersed institutional funding. We believe as an aspirational matter that it would be preferable if no center, institute, or program received a substantial share of its funding from a single source or from a multiplicity of sources whose preferences align on any significant issue of law or policy. Rather, it would be preferable if institutions received funding from a diversified group of sources whose preferences did not coincide, or at least from multiple sources with contrasting preferences. We recognize that this may be difficult or impossible for some institutions, particularly newer ones, and so we describe it as an aspirational goal rather than recommending that it be adopted immediately as a practical norm.

As a general matter, all donors should be identified. We recognize that in certain circumstances, individual donors may wish to remain anonymous in order to keep the extent of their giving capacity private. The best practice would be to avoid this. If that is impossible, anonymous donations should never be used for any other reason, such as masking a donor's interest in the topic or avoiding the potential implications for conflicts of interest. Corporate, foundation, and industry group donors should be identified under all circumstances.

\section{CALL FOR ACTION}

We consider this to be the beginning of a conversation and recognize that, even with these general guidelines, there is much work to be done. We urge all institutions involved in legal academic governance - including the American Bar Association, American Association of Law Schools, and others - to help develop and adopt these 
and other ethical norms for the field. In particular, we urge those institutions to aid in the creation of more detailed guidelines that expand upon the principles we have enunciated here, as well as exploring additional topics, such as personal equity holdings or ownership stakes. Conferences of academics, such as the Intellectual Property Scholars Conference or other groupings, could also be helpful in establishing careful governance processes so that our field can maintain and strengthen its formal ethical norms.

John Allison

University of Texas at Austin

McCombs Graduate School of

Business

James Bessen

Boston University School of Law

Jeremy Bock

University of Memphis Cecil C.

Humphreys School of Law

Robert A. Bohrer

California Western School of

Law

Sarah Burstein

The University of Oklahoma College of Law

Irene Calboli

Texas A\&M University School of

Law

Ralph D. Clifford

University of Massachusetts

School of Law

Julian Cockbain

Bioethics Institute Ghent

Lauren Cohen

Harvard Business School
Jorge Contreras

University of Utah S.J. Quinney

College of Law

Ben Depoorter

University of California, Has-

tings College of the Law

Dieter Ernst

East-West Center

Robin Feldman

University of California,

Hastings College of the Law

Brian Frye

University of Kentucky College

of Law

Laura N. Gasaway

University of North Carolina

School of Law

Shubha Ghosh

University of Wisconsin Law

School

Ove Granstrand

Chalmers University of

Technology

Marc Greenberg

Golden Gate University School of Law 
James Grimmelmann

University of Maryland Francis

King Carey School of Law

Umit Gurun

University of Texas at Dallas

Robert G. Harris

University of California, Berkeley Haas School of Business

Yaniv Heled

Georgia State University College of Law

Laura Heymann

William \& Mary Law School

Martin Husovec

Tilberg Law School

Ariel Katz

University of Toronto Faculty of Law

Scott Kominers

Harvard Business School

Sapna Kumar

University of Houston Law Center

Mark A. Lemley

Stanford Law School

Trudo Lemmens

University of Toronto Faculty of Law

Dave Levine

Elon University School of Law

Yvette Joy Liebesman
St. Louis University School of Law

Phil Malone

Stanford Law School

Gregory Mandel

Temple University Beasley

School of Law

Jonathan S. Masur

University of Chicago Law

School

Keith E. Maskus

University of Colorado, Boulder

Mark McKenna

Notre Dame Law School

Joseph Scott Miller

University of Georgia School of

Law

Lisa Larrimore Ouellette

Stanford Law School

Arti K. Rai

Duke Law School

Jason Rantanen

University of Iowa College of

Law

Amelia Smith Rinehart University of Utah College of Law

Jacob Rooksby

Duquesne University School of

Law

Matthew Sag

Loyola University Chicago

School of Law 
Sharon Sandeen

Mitchell Hamline School of Law

Joshua Sarnoff

DePaul University College of

Law

Arul George Scaria

National Law University, Delhi

Brenda Simon

Thomas Jefferson School of Law
Jennifer Urban

University of California, Berke-

ley School of Law

Liza Vertinsky

Emory University School of Law

Andrea Wallace

Ph.D. Candidate, University of Glasgow

Jonathan Zittrain

Harvard Law School

*The above-signed are not all drafters of this document, but signal their support for these principles. Institutional names are for identification purposes only. 